\title{
MORPHOLOGICAL JUSTIFICATION OF THE SALIVARY GLAND TISSUE RESECTION BOUNDARIES DURING SURGICAL TREATMENT OF PATIENTS WITH PLEOMORPHIC ADENOMAS
}

DOI: 10.36740/WLek202109127

\author{
Igor S. Brodetskyi ${ }^{1}$, Vladislav A. Malanchuk ${ }^{1}$, Olena 0. Dyadyk ${ }^{2}$, Yaroslava A. Kulbashna ${ }^{1}$, Olena 0. Astapenko ${ }^{1}$, \\ Nataliia V. Kapustnyk ${ }^{3}$, Mykhailo S. Myroshnychenko ${ }^{3}$ \\ 'BOGOMOLETS NATIONAL MEDICAL UNIVERSITY, KYIV, UKRAINE \\ ${ }^{2}$ SHUPYK NATIONAL HEALTHCARE UNIVERSITY OF UKRAINE, KYIV, UKRAINE \\ ${ }^{3}$ KHARKIV NATIONAL MEDICAL UNIVERSITY, KHARKIV, UKRAINE
}

\begin{abstract}
The aim is to substantiate morphologically the resection boundaries of the salivary gland tissue in the surgical treatment of patients with pleomorphic adenoma of different histological variants.

Materials and methods: The study used autopsy, surgical and biopsy material, divided into 2 groups. Group 1 included autopsy material $(n=6)$, represented by tissue fragments of the parotid salivary gland, in which macroscopic and microscopic examination did not reveal any general pathological processes. Group 2 included surgical and biopsy material from 30 patients, represented by pleomorphic adenomas with adjacent tissue of the salivary gland at a distance of $0.5 \mathrm{~cm}$ and $1.0 \mathrm{~cm}$. Histological, morphometric and statistical research methods were used.

Results: The morphological features of the salivary gland tissue which was adjacent to the pleomorphic adenoma at a distance of $1.0 \mathrm{~cm}$, practically corresponded to the physiological norm. However, the tissue of the salivary gland, bordering the tumor at a distance of $0.5 \mathrm{~cm}$, was characterized by pronounced changes. These changes were: violation of the ratio of the specific volumes of the parenchyma and stroma; atrophy of the terminal sections and ducts with cystic expansion of some ducts; thickening of the secretion and formation of calculi in the lumen of some ducts; atrophic and alterative changes in the epithelial lining the terminal sections and ducts; sclerosis and lipomatosis, areas with hyalinosis and dystrophic calcification in the stroma; hemodynamic disturbances in the stroma with a decrease in the number of vessels; pronounced focal or diffuse immune infiltration in the stroma in some areas with the lymphoid follicles formation.

Conclusion: The comprehensive study has confirmed that removal of the tumor with the adjacent tissue of the salivary gland at a distance of $1.0 \mathrm{~cm}$ in patients with pleomorphic adenoma of various histological variants is the most justified from the morphological point of view.
\end{abstract}

KEY WORDS: pleomorphic adenoma, salivary gland, resection boundaries, morphology

Wiad Lek. 2021;74(9 p.l):2182-2186

\section{INTRODUCTION}

Pleomorphic adenoma is the most common benign neoplasm of the salivary glands which accounts for 60 to $70 \%$ of all benign salivary gland tumors. It is histologically extremely heterogenous and has various clinical manifestations [1]. Pleomorphic adenoma is more commonly seen in the age group of $40-50$ years, with $1-5 \%$ in the age of 16 years or older [2].

Patients with pleomorphic adenoma of the salivary glands often undergo surgical treatment - tumor resection with the adjacent tissue of the salivary gland with mandatory preservation of the branches of the facial nerve $[3,4]$. Removing the tissue of the salivary gland, which borders on the pleomorphic adenoma, decreases the risk of tumor recurrence. In the domestic and foreign literature, there are no scientifically substantiated recommendations on the resection boundaries of the salivary gland tissue in the surgical treatment of patients with pleomorphic adenoma, which actualizes this study.

\section{THE AIM}

The aim is to substantiate morphologically the resection boundaries of the salivary gland tissue in the surgical treatment of patients with pleomorphic adenoma of different histological variants.

\section{MATERIALS AND METHODS}

The study used autopsy, surgical and biopsy material, divided into 2 groups.

Group 1 included autopsy material $(n=6)$, represented by tissue fragments of the parotid salivary gland. This material was collected during autopsies at the pathological anatomy department of the Communal non-profit enterprise of Kyiv Regional Council "Kyiv Regional Clinical Hospital". Macroscopic and microscopic examination did not reveal any general pathological processes in the salivary glands. The cause of death of these persons was chronic cardiac or cardiopulmonary insufficiency. 


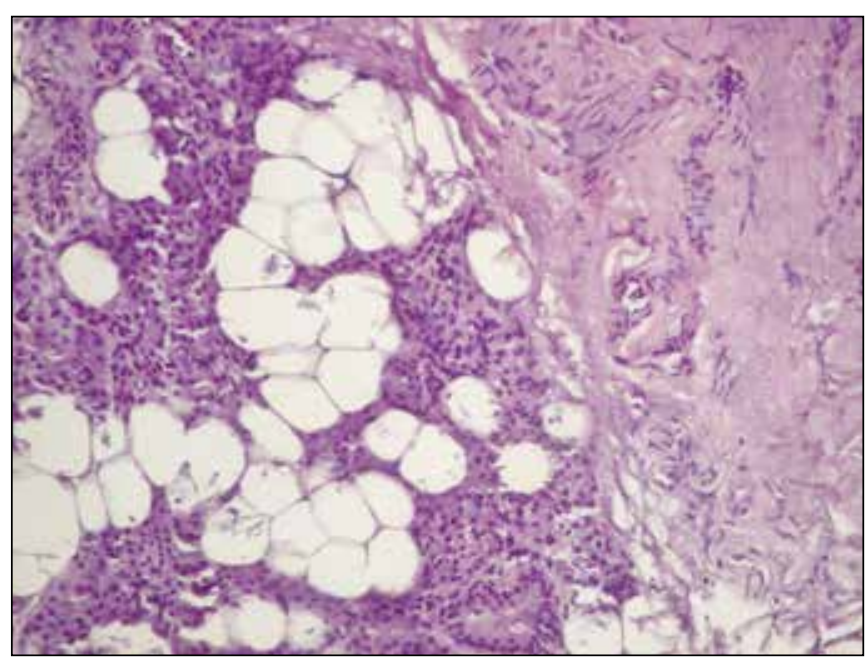

Fig. 1. The salivary gland, which was adjacent to the pleomorphic adenoma at a distance of $0.5 \mathrm{~cm}$. Atrophy of the parenchyma, sclerosis and lipomatosis of the stroma. Hematoxylin and eosin staining,$\times 200$.

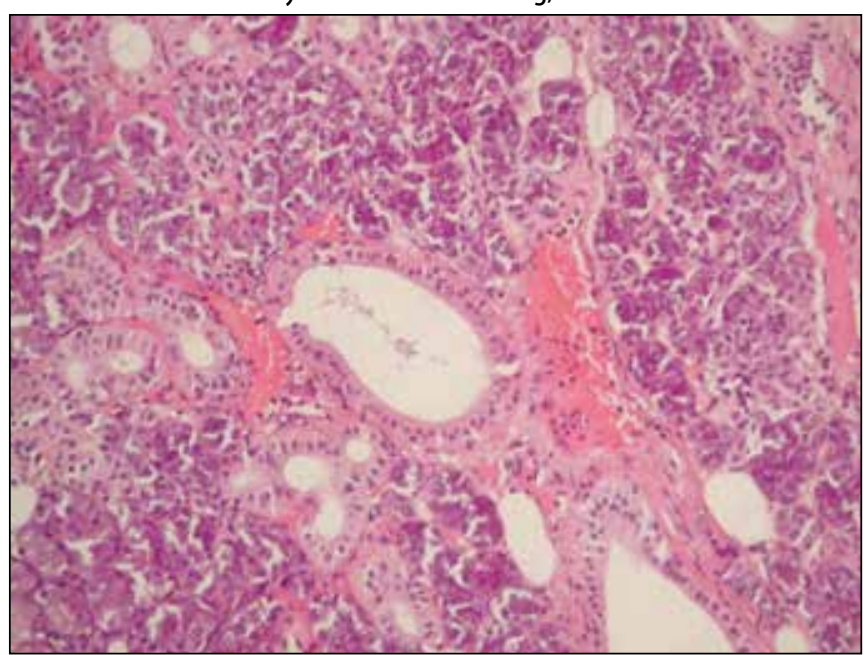

Fig. 2. The salivary gland, which was adjacent to the pleomorphic adenoma at a distance of $0.5 \mathrm{~cm}$. Alterative changes in the epithelium of the terminal sections and ducts. Hemodynamic disorders in the stroma. Hematoxylin and eosin staining, $\times 200$.

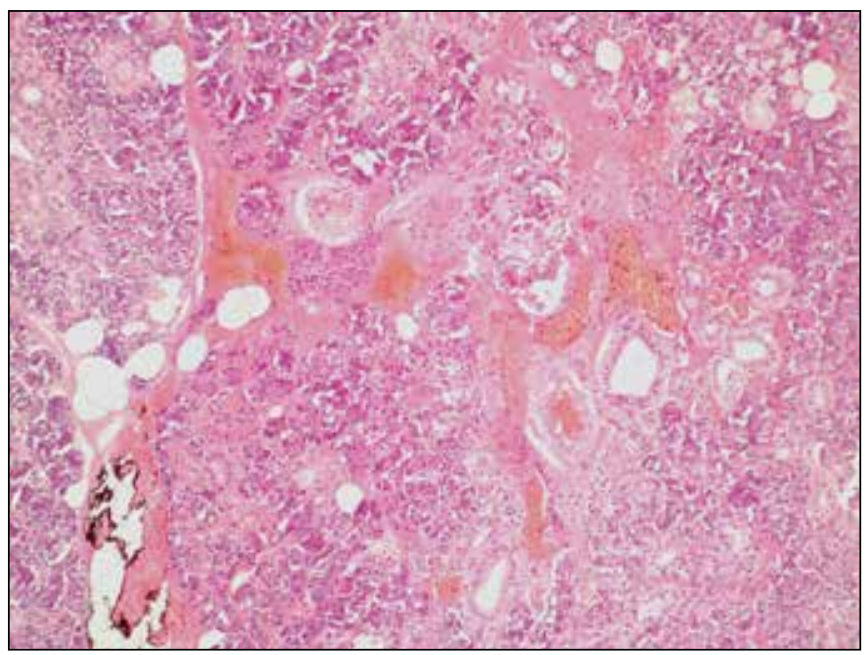

Fig. 3. The salivary gland, which was adjacent to the pleomorphic adenoma at a distance of $0.5 \mathrm{~cm}$. Hemodynamic disorders, areas of hyalinosis and dystrophic calcification, fat cells groups in the stroma. Hematoxylin and eosin staining, $\times 100$.
Group 2 included surgical and biopsy material from 30 patients, represented by pleomorphic adenomas with adjacent tissue of the salivary gland at a distance of $0.5 \mathrm{~cm}$ and $1.0 \mathrm{~cm}$. Among all cases of pleomorphic adenomas, we revealed a mesenchymal variant in 15 cases, mixed variant - in 10 cases, epithelial variant - in 5 cases.

The resulting material was fixed in a $10 \%$ solution of neutral buffered formalin according to the generally accepted technique and embedded in paraffin. Serial sections 3-4 $\mu \mathrm{m}$ thick were made from paraffin blocks. The authors studied the slides stained with hematoxylin and eosin using an Olympus BX-41 microscope (Japan), processed with the Olympus DP-soft version 3.1 software, used in a morphometric study. During morphometry in the field of view of the microscope at a magnification of $\times 100$ we determined specific volumes of the terminal sections and ducts, connective tissue, vessels, and adipose tissue in the tissue of the salivary gland.

The obtained digital data were statistically processed, using the Statistica 10.0 program. The average values of indicators in the groups were compared using the nonparametric Mann-Whitney U test. Differences were considered significant at $\mathrm{p}<0.05$.

\section{RESULTS AND DISCUSSION}

In the survey microscopy in group 1 , the salivary gland was represented by complex alveolar or alveolar-tubular glands. The latter consisted of terminal sections and ducts, lined with epithelial cells from the inside. The terminal sections, taking into account their morpho-functional features, were of three types: mucous, proteinaceous and mixed. The excretory ducts were subdivided into intralobular, interlobular and gland ducts. Layers of loose connective tissue surrounded the terminal sections and ducts, between its fibers there were vessels of various sizes. A few immune cells were found in the single fields of vision between the connective tissue fibers.

During morphometry of the salivary gland, we noted that the specific volume of the parenchyma $((82.8 \pm 5.3) \%)$, represented by the terminal sections and ducts, prevailed $(p<0.05)$ over the specific volume of the stroma, characterized by connective tissue fibers $((11.8 \pm 2.1) \%)$ and vessels ((5.4 \pm 1.6$) \%)$.

The morphological features of the salivary gland which we identified in group 1 correspond to the physiological norm and coincide with the data of other scientists [5].

In group 2 we revealed clearly pronounced structural changes in both the parenchymal and stromal components in the tissue of the salivary gland adjacent to the pleomorphic adenoma at a distance of $0.5 \mathrm{~cm}$.

The parenchymal component was characterized by moderate or severe atrophic changes (fig. 1). The authors found cystic dilated ducts in a significant number of visual fields against the background of atrophic terminal sections and ducts. Thickening of the secretion and the formation of small calculi were revealed in some excretory ducts lumen. The epithelial lining of the terminal sections and ducts 


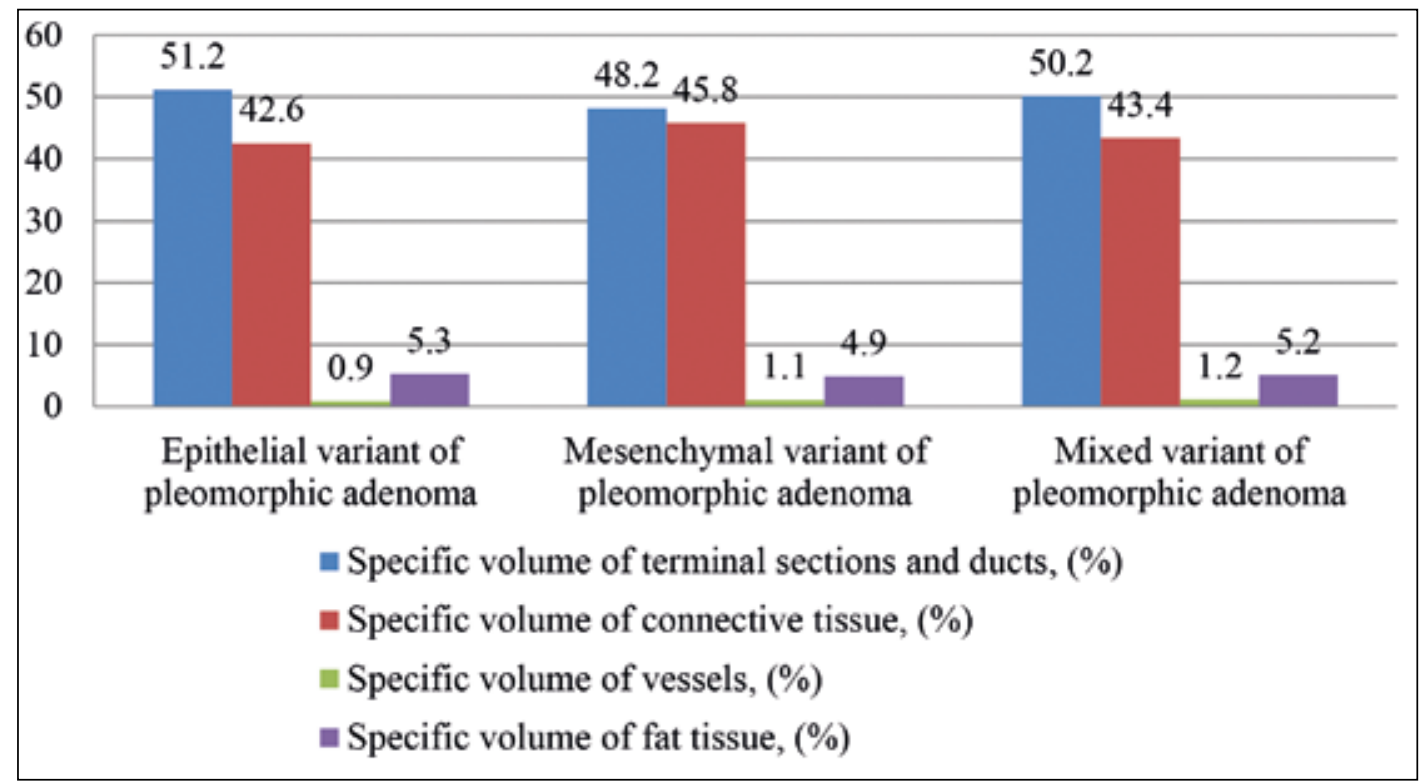

Fig. 4. The average values of the specific volumes of the main structural elements of the salivary gland tissue, which was adjacent to the pleomorphic adenoma of various histological variants at a distance of $0.5 \mathrm{~cm}$.

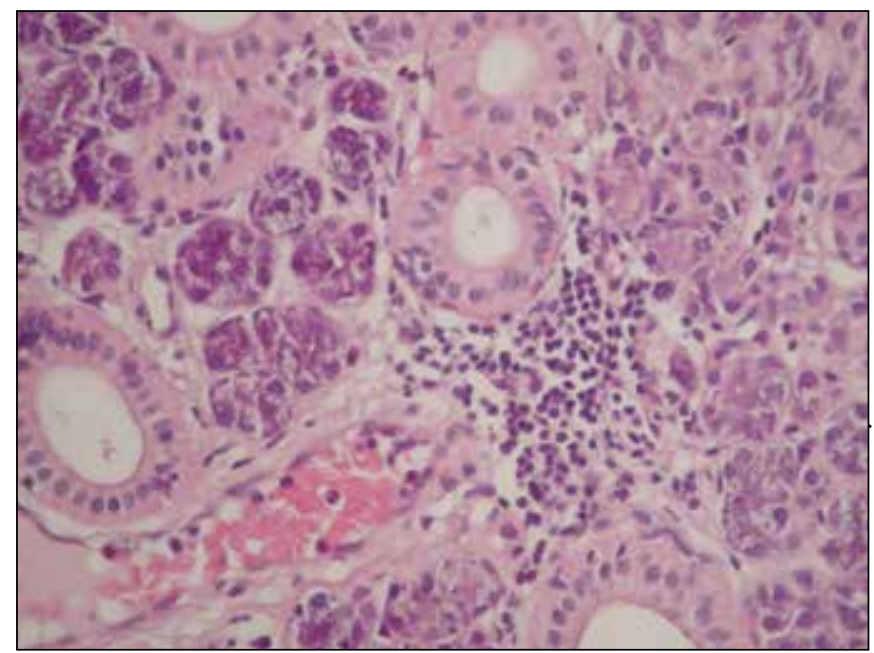

Fig. 5. The salivary gland, which was adjacent to the pleomorphic adenoma at a distance of $1.0 \mathrm{~cm}$. Focal alterative changes in the epithelial cells of single terminal sections and ducts. Focal accumulation of immune cells in the stroma. Hematoxylin and eosin staining, $\times 400$. infiltration by immune cells between the fibers of the connective tissue and around the vessels. Small lymphoid follicles formed in single visual fields. Hemodynamic disturbances developed almost in all cases characterized by edematous changes, vascular congestion and formation of small diapedetic hemorrhages (fig. 2, 3).

Morphometric examination of the salivary gland, adjacent to the pleomorphic adenoma of different histological variants at a distance of $0.5 \mathrm{~cm}$, revealed a decrease $(p<0.05)$ of the specific volume of vessels, terminal sections and ducts, an increase $(p<0.05)$ of the specific volume of connective tissue, compared with the indicators of group 1 (fig. 4). The specific volumes of the main structural elements of the salivary gland tissue, adjacent to the pleomorphic adenoma at a distance of $0.5 \mathrm{~cm}$, did not depend on the histological variant of the tumor. In this group, in contrast to group 1 , there was no difference $(p>0.05)$ between the specific volumes of the parenchyma and stroma

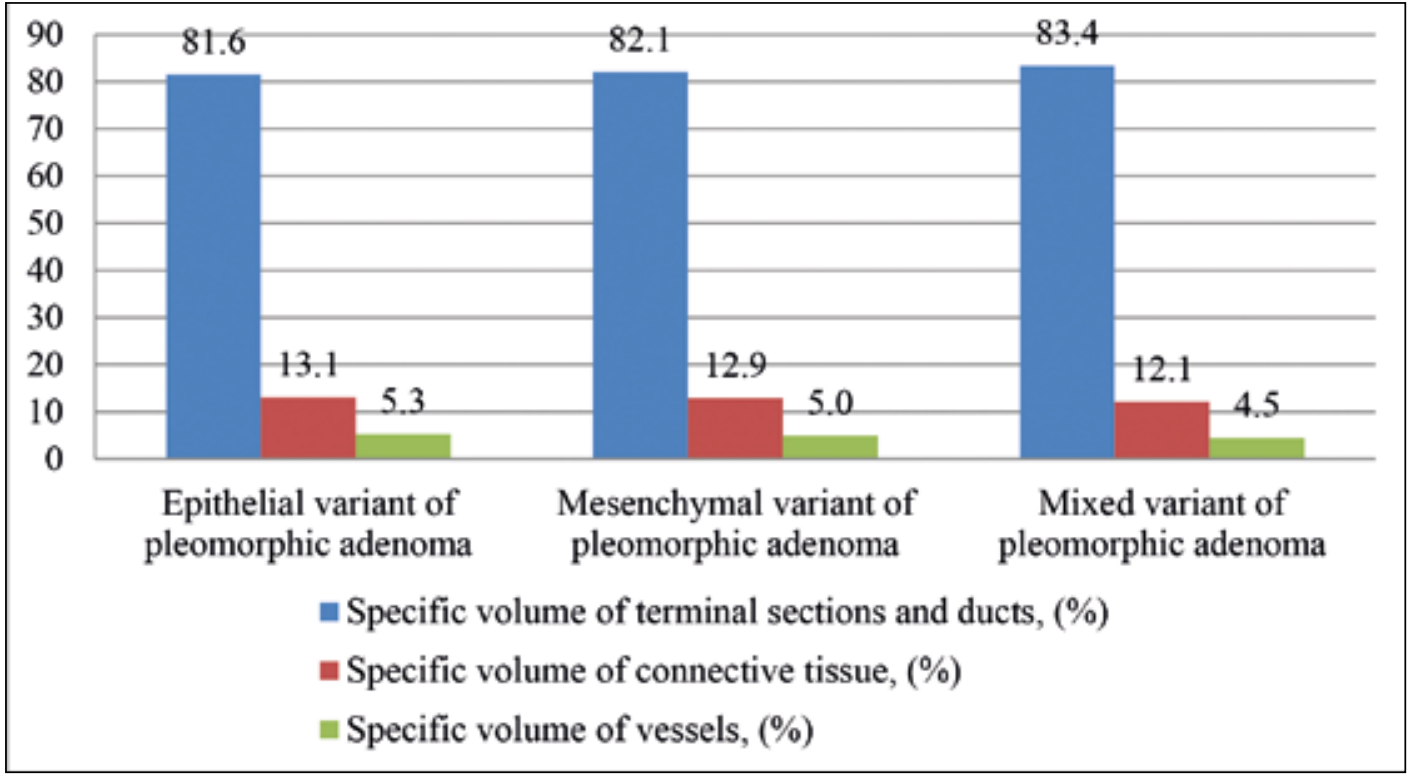

Fig. 6. The average values of the specific volumes of the main structural elements of the salivary gland tissue, which was adjacent to the pleomorphic adenoma of various histological variants at a distance of $1.0 \mathrm{~cm}$. 
of the salivary gland, adjacent to the pleomorphic adenoma of different histological variants at a distance of $0.5 \mathrm{~cm}$.

Thus, structural changes in the salivary gland, located at a distance of $0.5 \mathrm{~cm}$ from the pleomorphic adenoma of various histological variants, revealed during the survey microscopy and morphometric study, were irreversible and will lead to its dysfunction. The latter will be manifested by changes in the qualitative and quantitative characteristics of saliva, which in the future can lead to the development of diseases of the oral mucosa and teeth.

In the salivary gland, adjacent to the pleomorphic adenoma at a distance of $0.5 \mathrm{~cm}$, the revealed sclerotic changes, from our point of view, were due to hypoxia. Hypoxia, according to many scientists, is one of the main pathogenetic factors in the development of sclerosis in various organs of the human body [6-8]. The development of hypoxia in the areas of the salivary gland adjacent to the tumor was due, among other things, to a decrease in the content of various sizes vessels in them, as evidenced by the results of our morphometric study. In response to hypoxia, hemodynamic changes developed in these tissues, which in turn led to trophic disorders.

The structural changes, which we identified in the salivary gland located at a distance of $0.5 \mathrm{~cm}$ from the pleomorphic adenoma, were similar to those described by many scientists in chronic sialoadenitis [9].

The authors found focal moderate alterative changes in epithelial cells in single terminal sections and ducts in the tissue of the salivary gland, located at a distance of $1.0 \mathrm{~cm}$ from the pleomorphic adenoma of different histological variants (fig. 5). Focal accumulations of immune cells were found in some places in the stroma (fig. 5). In morphometry in these areas of the salivary gland tissue, as in group 1 , we found a predominance $(\mathrm{p}<0.05)$ of the specific volume of the parenchyma over the specific volume of the stroma (fig. 6). Moreover, in these areas, the indices of the specific volumes of the terminal sections and ducts, vessels, connective tissue did not differ $(\mathrm{p}>0.05)$ from the indices of group 1 . The indices of the specific volumes of the main structural elements of the salivary gland tissue, adjacent to the pleomorphic adenoma at a distance of $1.0 \mathrm{~cm}$, did not depend on the histological variant of the tumor.

Analysis of survey microscopy and morphometric research results in group 2 showed that the tissue of the salivary gland, adjacent to the pleomorphic adenoma of various histological variants at a distance of $1.0 \mathrm{~cm}$, practically corresponded to the physiological norm. However, there were marked irreversible structural changes at a distance of $0.5 \mathrm{~cm}$ from the tumor in the tissue of the salivary gland. In our opinion, the latter will grow, progress and spread to the adjacent areas of the salivary gland over time, resulting in its dysfunction.

Thus, our comprehensive study has confirmed that removal of the tumor with the adjacent tissue of the salivary gland at a distance of $1.0 \mathrm{~cm}$ in patients with pleomorphic adenoma of various histological variants is the most justified from the morphological point of view. Our earlier genetic and immunohistochemical studies also confirmed the validity of this criterion $[4,10]$.

\section{CONCLUSIONS}

It is morphologically justified to remove the tumor with the adjacent tissue of the salivary gland at a distance of $1.0 \mathrm{~cm}$ in patients with pleomorphic adenoma of various histological variants. The morphological features of the latter salivary gland tissue practically correspond to the physiological norm. However, the tissue of the salivary gland, bordering the tumor at a distance of $0.5 \mathrm{~cm}$, is characterized by pronounced changes. These changes are: violation of the ratio of the specific volumes of the parenchyma and stroma; atrophy of the terminal sections and ducts with cystic expansion of some ducts; thickening of the secretion and formation of calculi in the lumen of some ducts; atrophic and alterative changes in the epithelial lining of the terminal sections and ducts; sclerosis and lipomatosis, areas with hyalinosis and dystrophic calcification in the stroma; hemodynamic disturbances in the stroma with a decrease in the number of vessels; pronounced focal or diffuse immune infiltration in the stroma in some areas with the formation of lymphoid follicles.

\section{REFERENCES}

1. Choi JS, Cho BH, Kim HJ, et al. Identification of new genes of pleomorphic adenoma. Medicine (Baltimore). 2019;98(51):e18468. doi: 10.1097/ MD.0000000000018468.

2. Jain S, Hasan S, Vyas N, et al. Pleomorphic adenoma of the parotid gland: report of a case with review of literature. Ethiopian Journal of Health Sciences. 2015;25(2):189-194.

3. Almeslet AS. Pleomorphic Adenoma: A Systematic Review. International Journal of Clinical Pediatric Dentistry. 2020;13(3):284-287.

4. Brodetskyi IS, MalanchukVO. Obgruntuvannja hirurgichnogo likuvannja hvoryh pleomorfnymy adenomamy slynnyh zaloz [Substantiation of the surgical treatment of patients with pleomorphic adenomas of salivary glands]. Stomatological Bulletin. 2020;38(4/113):48-52. (Ua).

5. Porcheri C, Mitsiadis TA. Physiology, pathology and regeneration of salivary glands. Cells. 2019;8(9):976. doi: 10.3390/cells8090976.

6. Lee JW, Ko J, Ju C, Eltzschig HK. Hypoxia signaling in human diseases and therapeutic targets. Experimental and Molecular Medicine. 2019;51(6):1-13. doi: 10.1038/s12276-019-0235-1.

7. Krasnoselsky MV, Pushkar OS, Simonova LI, Myroshnychenko MS. The effect of photodynamic therapy and platelet-enriched plasma on the healing of skin radiation ulcers infected by Staphylococcus aureus. Problems of Radiation Medicine and Radiobiology. 2020;25:338-358.

8. Sorokina IV, Myroshnychenko MS, KapustnykNV, etal. Morfologicheskaja harakteristika soedinitelnoj tkani pochek donoshennyh plodov i novorozhdennyh ot materej, beremennost kotoryh oslozhnilas prejeklampsiej razlichnoj stepeni tjazhesti [Morphological characteristics of kidneys connective tissue of mature fetuses and newborns from mothers, whose pregnancy was complicated by preeclampsia of varying degrees of severity]. Wiadomości Lekarskie. 2018;71(3 pt 1):579-587. (Ru).

9. Levkiv MO. Morfologichni osnovy rozvytku hronichnogo interstycijnogo sialoadenitu pry patologii'gepatobiliarnoi'systemy [Morphological basis of chronic interstitial sialoadenit in the case of hepato-biliary system disease]. Clinical dentistry. 2016;3:4-9. (Ua)

10. Brodetskyi IS, MalanchukVO, Dosenko VE. Expressions of microRNA-29a and microRNA-34a in pleomorphic adenomas of salivary glands. Gland Surgery. 2020;9(6):1914-1923. 
ORCID and contributionship:

Igor S. Brodetskyi: 0000-0002-9434-4079 ${ }^{A, D, E}$

Vladislav A. Malanchuk: 0000-0001-8111-0436

Olena O. Dyadyk: 0000-0002-9912-4286 ${ }^{\text {, }}$

Yaroslava A. Kulbashna: 0000-0002-2571-091X $X^{C, F}$

Olena O. Astapenko: 0000-0002-2168-9439 ${ }^{C, F}$

Nataliia V. Kapustnyk: 0000-0002-4875-398X ${ }^{B, F}$

Mykhailo S. Myroshnychenko: 0000-0002-6920-8374

\section{Conflict of interest:}

The Authors declare no conflict of interest.

\section{CORRESPONDING AUTHOR}

Mykhailo S. Myroshnychenko

Pathological Anatomy Department,

Kharkiv National Medical University

str. Svetlaya 27A, apt. 70, 61129, Kharkiv, Ukraine

tel: $+380501699763,+380961033038$

e-mail:msmyroshnychenko@ukr.net

Received: 20.06.2021

Accepted: 25.08 .2021

A - Work concept and design, B - Data collection and analysis, C - Responsibility for statistical analysis,

D-Writing the article, $\mathbf{E}$-Critical review, $\mathbf{F}$ - Final approval of the article 